\title{
Infra-specific morphological, anatomical and genetic variations in Lallemantia peltata(L.) Fisch. \& C. A. Mey. (Lamiaceae)
}

\author{
Masoud Sheidai ${ }^{1}$, Zeynab Moradian Poode ${ }^{1}$, Fahimeh Koohdar ${ }^{1}$, Seyed Mehdi Talebi ${ }^{2 *}$ \\ ${ }^{1}$ Faculty of Life Sciences \& Biotechnology, Shahid Beheshti University, Tehran, Iran. \\ ${ }^{2}$ Department of Biology, Faculty of Science, Arak University, Arak 38156-8-8349, Iran. \\ *Author for correspondence: seyedmehdi_talebi@yahoo.com
}

\begin{abstract}
Lallemantia is a small genus with 5 species, which one of them is Lallemantia peltata. This aromatic plant grows in a limited area of the Iran and is known as medicinal herb in folk medicine. We have no information on the infraspecific variations on morphological, anatomical and molecular features of this species. Therefore, in the current study; we investigated these variations on six geographical populations of it. These plants were used for morphological, anatomical and molecular investigations. GenAlex, GenoDive and PAST softwares were used for statistical analyses. In morphological study, we used fifteen characteristics. PCA bi-plot revealed some characteristics had diagnostic value in separation of the populations. The studied populations were clustered into two groups. We examined fifteen qualitative and quantitative anatomical variables. PCA loading revealed that some anatomical variables had the highest positive correlation and were the most variable anatomical characters among the studied populations. Based on the anatomical traits, theses populations divided into two groups. Ten ISSR primers were used for examination of genetic variations among the populations. The STRUCTURE analyses of ISSR data revealed two groups in theses populations that they were divided into two groups in MDS plot. The results of morphological, anatomical and also ISSR studies were similar. Clustering and ordination of the studied populations separated some of these populations from the others and suggest the existence of two groups within this species.
\end{abstract}

Key words: Lallemantia peltata, Anatomy, Morphology, ISSR, infraspecific variations.

\section{Introduction}

Lallemantia Fisch. \& C.A. Mey. is a genus of family Lamiaceae. It is a small genus with five species that are herbaceous annual or biennial plants, characterized by simple leaves; a thyrsoid, spike-like or oblong, often interrupted inflorescence; ovate to rotund or sometimes linear, aristate-toothed bracteoles; and oblong, trigonous, smooth and mucilaginous nutlets (Jamzad, 2012). Some of these aromatic species are of medicinal value (Mahmood et al., 2013), while others have been used as the source of food and industrial plant (Rivera, Obón, 1992).

Lallemantia species are widely distributed in various parts of the world such as Afghanistan, China, India, Kazakhstan, Kyrgyzstan, Pakistan, Iran, Russia, Tajikistan, Turkmenistan, Uzbekistan, SW Asia and Europe, with the Caucasian region as the center of its origin. All five Lallemantia species occur in Iran (Rechinger, 1982; Jamzad, 2012). In general, limited biosystematics and molecular studies have been performed on this genus (see for example, Koohdar et al., 2015).

Infra-specific taxonomic entities can be identified after a detailed population-based investigation within plant species. In general, extensive morphological and genetic divergence among populations is the advent of speciation events. Intra-specific variation occurs within both wild as well as cultivated crop plants (Maxted, Hunter, 2011). Within the crop plants, variation may be in morphological, anatomical, karyological, ecological, physiological, biochemical and molecular characteristics. Explanatory surveys of genetic diversity can be useful preliminaries to germplasm collecting (Maxted, Hunter, 2011). 
Molecular methods for characterizing genetic diversity developed enormously and techniques such as ISSRs, microsatellites or AFLPs, have been extensively applied particularly to geographically differentiated populations (Sheidai et al., 2012; Sheidai et al., 2014; Koohdar et al., 2015,). Nevertheless, at this level, collecting strategies in wild species is still a matter of determining the size of the sample per site (population/ subpopulation) and the number of sites that need to be sampled to ensure appropriate allelic retention.

Lallemantia peltata (L.) Fisch. \& C. A. Mey. grows in limited area of the country and is known as medicinal plant that contains volatile and essential oil (Sefidkon et al., 2006). During our extensive Lallemantia plant collection from 2015 to 2018, we encountered morphological variation in different geographical populations of L. peltata. Therefore, we performed detailed morphometric, anatomical and molecular investigation of these populations with the aim to identify potential infra-specific taxonomic rank within L. peltata. To our knowledge this is the first time report on intra-specific variability in this species.

\section{Material and methods \\ Plant material}

In total 47 plant specimens of L. peltata were collected randomly from six geographical populations and were identified based on the descriptions provided in Flora of Iran (Jamzad, 2012). These plants were used for morphological, anatomical and molecular investigations. Details of populations are provided in Table 1.

Table1. Populations studied their locality and their localities adress.

$\begin{array}{ll}\text { population } & \text { localities } \\ \text { Saqqez } & \text { Kurdistan province, Marivan to Saqqez, } 1850 \mathrm{~m} . \\ \text { Asera } & \text { Albourz, province Chalous road, Asera, } 2000 \mathrm{~m} . \\ \text { Shahrestanak } & \text { Albourz province, Shahrestanak, } 1950 \mathrm{~m} . \\ \text { Fasham } & \text { Tehran province, Fasham, } 2100 \mathrm{~m} . \\ \text { Gachsar } & \text { Albourz province, Gachsar, } 1750 \mathrm{~m} . \\ \text { Gajereh } & \text { Albourz province, Gajereh, } 1950 \mathrm{~m} .\end{array}$

\section{Morphometry}

For morphological analyses, we used fifteen vegetative and reproductive morphological characteristics. Data were obtained from 5 to 10 randomly collected plants in each population. The studied morphological traits were: plant height, petiole length, basal leaf length and width, basal leaf length/width ratio, length and width of bract, bract length/width ratio, bract arista length, calyx and corolla length, calyx / corolla length ratio, nutlet length and width and nutlet length/width ratio.

Morphological variables were standardized (mean $=1$, variance $=0$ ), and used for multivariate statistical analyses. We used different clustering as well as ordination methods to study morphological divergence of the populations. These methods are UPGMA (Unweighted paired group using mean average) and PCoA (Principal coordinate analysis). PCA biplot (Principal components analysis) was used to identify the most variable morphological characters among the studied populations (Podani, 2000).

\section{Anatomical study}

For anatomical investigations embedded materials were prepared as follow: adult plant samples were excised and immediately fixed in formalin-acetic acid-alcohol solution (FAA) (formalin 5\%: acetic acid 5\% and ethanol 90\%) for 48 to 72 $\mathrm{h}$, and stored at $4{ }^{\circ} \mathrm{C}$ until sectioning. Then dehydrated in a graded ethanol series and embedded in $70 \%$ ethanol. Transverse hand sections of the stem samples were washed with distilled water and placed in $5 \%$ sodium hypochlorite solution for $20 \mathrm{~min}$. for clearing and rinsed with distilled water. The sections were stained with methyl blue and carmine and mounted on the slides using Canada balsam. Thin cut sections were observed using a microscope and images were taken using a digital camera.

In total fifteen anatomical traits of the stem were used. The studied anatomical features were: epidermal cell length, collenchyma cell length, parenchyma cell length, sclerenchyma cell length, xylem and phloem cell diameter, parenchyma and collenchyma cell layer number, pith cell length, stem width, xylem cell layer number.

Anatomical characters were first standardized (Mean $=0$, Variance $=1$ ) and used to establish the Euclidean distance among pairs of populations (Podani 2000). For grouping of the plant specimens, PCoA was used (Podani, 2000). PCA (Principal components analysis) was used to identify the most variable anatomical characters among the studied populations. PAST version 2.17 (Hammer et al., 2001) was used for multivariate analyses. 


\section{ISSR analysis}

The fresh leaves were collected randomly in each of the studied populations and dried in silica gel powder. Genomic DNA was extracted using CTAB with activated charcoal protocol (Sheidai et al., 2013). The quality of extracted DNA was examined by running on $0.8 \%$ agarose gel.

Ten ISSR primers; (AGC) $)_{5} \mathrm{GT}$, (CA) $)_{7} \mathrm{GT}$, (AGC) $)_{5} \mathrm{GG}, \mathrm{UBC} 810$, (CA) $)_{7} \mathrm{AT},(\mathrm{GA})_{9} \mathrm{C}, \mathrm{UBC} 807, \mathrm{UBC} 811,(\mathrm{GA})_{9} \mathrm{~A}$ and $(\mathrm{GT})_{7} \mathrm{CA}$ commercialized by UBC (the University of British Columbia) were used. PCR reactions were performed in a $25 \mu$ l volume containing $10 \mathrm{mM}$ Tris- $\mathrm{HCl}$ buffer at pH 8; $50 \mathrm{mM} \mathrm{KCl} ; 1.5 \mathrm{mM} \mathrm{MgCl} ; ; 0.2 \mathrm{mM}$ of each dNTP (Bioron, Germany), $0.2 \mu \mathrm{M}$ of a single primer; $20 \mathrm{ng}$ genomic DNA and $3 \mathrm{U}$ of Taq DNA polymerase (Bioron, Germany).

The amplifications' reactions were performed in a Techne thermocycler (Germany) with the following program: 5 min. initial denaturation step $94^{\circ} \mathrm{C}, 30 \mathrm{~S}$ at $94^{\circ} \mathrm{C} ; 1 \mathrm{~min}$. at $50^{\circ} \mathrm{C}$ and $1 \mathrm{~min}$. at $72^{\circ} \mathrm{C}$. The reaction was completed by a final extension step of $7 \mathrm{~min}$. at $72^{\circ} \mathrm{C}$. The amplification products were visualized by running on $2 \%$ agarose gel, followed by the ethidium bromide staining. The fragment size was estimated by using a $100 \mathrm{bp}$ molecular size ladder (Fermentas, Germany).

ISSR bands obtained were coded as binary characters (presence $=1$, absence $=0$ ). The following genetic diversity parameters were determined in each population: percentage of allelic polymorphism, allele diversity (Weising et al., 2005), Nei's gene diversity $(H)$, Shannon information index (I), number of effective alleles, and percentage of polymorphism (Freeland et al., 2011).

We used MDS plot for grouping of the plant populations. AMOVA (Analysis of molecular variance) test (with 1000 permutations) as implemented in GenAlex 6.4 (Peakall, Smouse, 2006), and Nei's $G_{\text {st }}$ analysis of GenoDive ver.2 (2013) (Meirmans , Van Tienderen, 2004), were used to reveal significant genetic difference among the studied populations (Sheidai et al., 2014).

$$
\mathrm{G}_{\mathrm{ST}}=\frac{H t-H s}{H t}
$$

(Ht is heterozygosity over all populations, Hs is mean heterozygosity within the populations (Hedrick, 2005).

Bayesian based model STRUCTURE analysis (Pritchard et al., 2000) were used to study the genetic structure of populations (Sheidai et al., 2014). For STRUCTURE analysis, data were scored as dominant markers (Falush et al., 2007). The Evanno test was performed on STRUCTURE result to find the proper number of $K$ by using delta $K$ value (Evanno et al., 2005). We performed K-Means clustering as done in GenoDive ver. 2. (2013). Two summary statistics, 1- pseudo-F (Caliński, Harabasz, 1974) and 2- Bayesian Information Criterion (BIC) (Schwarz, 1978) provide the best fit for k (Meirmans, 2012; Meirmans, Van Tienderen, 2004). Pseudo-F (Caliński, Harabasz, 1974) relates $r 2$, the fraction of the total variance that is explained by the clustering, to the number of clusters $k$ and the number of population's $n: F_{k}=r^{2} /\left(1-r^{2}\right)(n-k)$. Where $r^{2}=\left(\right.$ SSDT - SSDAP/WG)/(SSDT-SSDWP). The Bayesian Information Criterion $(B I C)$ is calculated as: BIC $_{k}=n$. In $($ SSE) $+k$. $\ln (n)$.

\section{Results \\ Morphometry}

Details of morphological characteristics in six studied populations are provided in Table 2. The highest and shortest stems were recorded in Saqqez and Fasham populations, respectively. We found largest and smallest basal leaves size, petiole, corolla and calyx length in Shahrestanak and Gachsar populations, respectively. However, the biggest bract size was observed in Fasham population, but Gachsar population had the smallest bract. Fasham population had biggest nutlet, while smallest nutlet was seen in Asera population.

Table2. Details of morphological characters in L. peltata populations studied (all values are in $\mathrm{mm}$ ).

\begin{tabular}{lllllll}
\hline \multicolumn{1}{c}{ Populations } & Saqqez & Asera & Shahrestanak & Fasham & Gachsar & Gajereh \\
Characters & & & & & & \\
& & & & & & \\
Plant Height & 849.0 & 475.0 & 244.0 & 191.0 & 425.0 & 168.0 \\
Petiole Length & 17.60 & 3.0 & 19.80 & 11.80 & 5.0 & 12.60 \\
Basal leaf length & 9.0 & 3.17 & 23.0 & 22.90 & 7.17 & 16.20 \\
Basal leaf width & 5.30 & 2.0 & 9.0 & 6.80 & 4.0 & 7.30 \\
Basal leaf length/width ratio & 1.69 & 1.58 & 2.55 & 3.36 & 1.79 & 2.21 \\
Bract length & 7.80 & 6.84 & 6.60 & 7.70 & 5.17 & 6.10 \\
Bract width & 5.80 & 3.50 & 5.60 & 6.80 & 4.34 & 5.60 \\
Bract length/width ratio & 1.34 & 1.95 & 1.17 & 1.13 & 1.19 & 1.08 \\
Calyx length & 13.0 & 13.5 & 14.20 & 12.30 & 10.0 & 12.02 \\
Corolla length & 10.60 & 8.34 & 10.60 & 9.40 & 8.0 & 9.60 \\
Calyx / corolla length ratio & 1.22 & 1.61 & 1.33 & 1.30 & 1.25 & 1.27 \\
Nutlet length & 4.90 & 3.0 & 10.30 & 15.20 & 6.50 & 8.20 \\
Nutlet width & 1.08 & 0.70 & 4.20 & 4.20 & 1.35 & 3.27 \\
Nutlet length/width ratio & 4.53 & 4.28 & 2.45 & 3.58 & 4.81 & 2.50 \\
Bract arista length & 3.60 & 1.84 & 2.80 & 2.30 & 2.17 & 2.10 \\
\hline
\end{tabular}


UPGMA clustering (Fig. 2) of the studied populations based on the morphological variables produced two major clusters. In the first major cluster, mostly plants of the populations Saqqez, Asera, and Gachsar are placed inter-mixed together. The studied plants of the populations Shahrestanak, Fasham, and Gajereh comprised the second major cluster. This inter-mixed placement of plants indicates some degree of morphological overlaps among the studied populations.

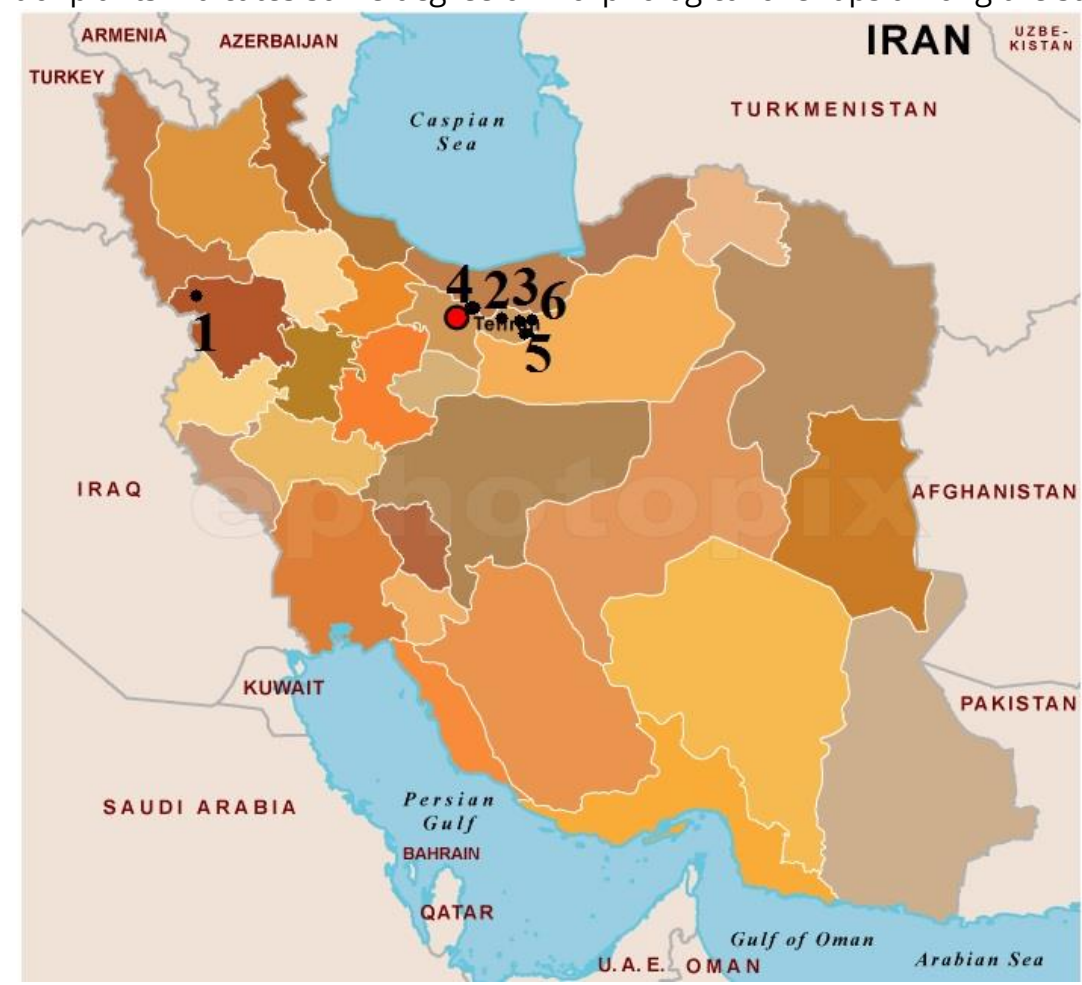

Fig.1. Distribution map of L. peltata populations.

PCoA plot (Fig. 3) of the studied populations based on the morphological features revealed morphological divergence of populations Saqqez, Asera, and Gachsar, while plants of the populations Shahrestanak, Fasham, and Gajereh were placed inter-mixed. PCA bi-plot revealed characteristics like, plant height, length of bract arista and the length of corolla can differentiate two groups.

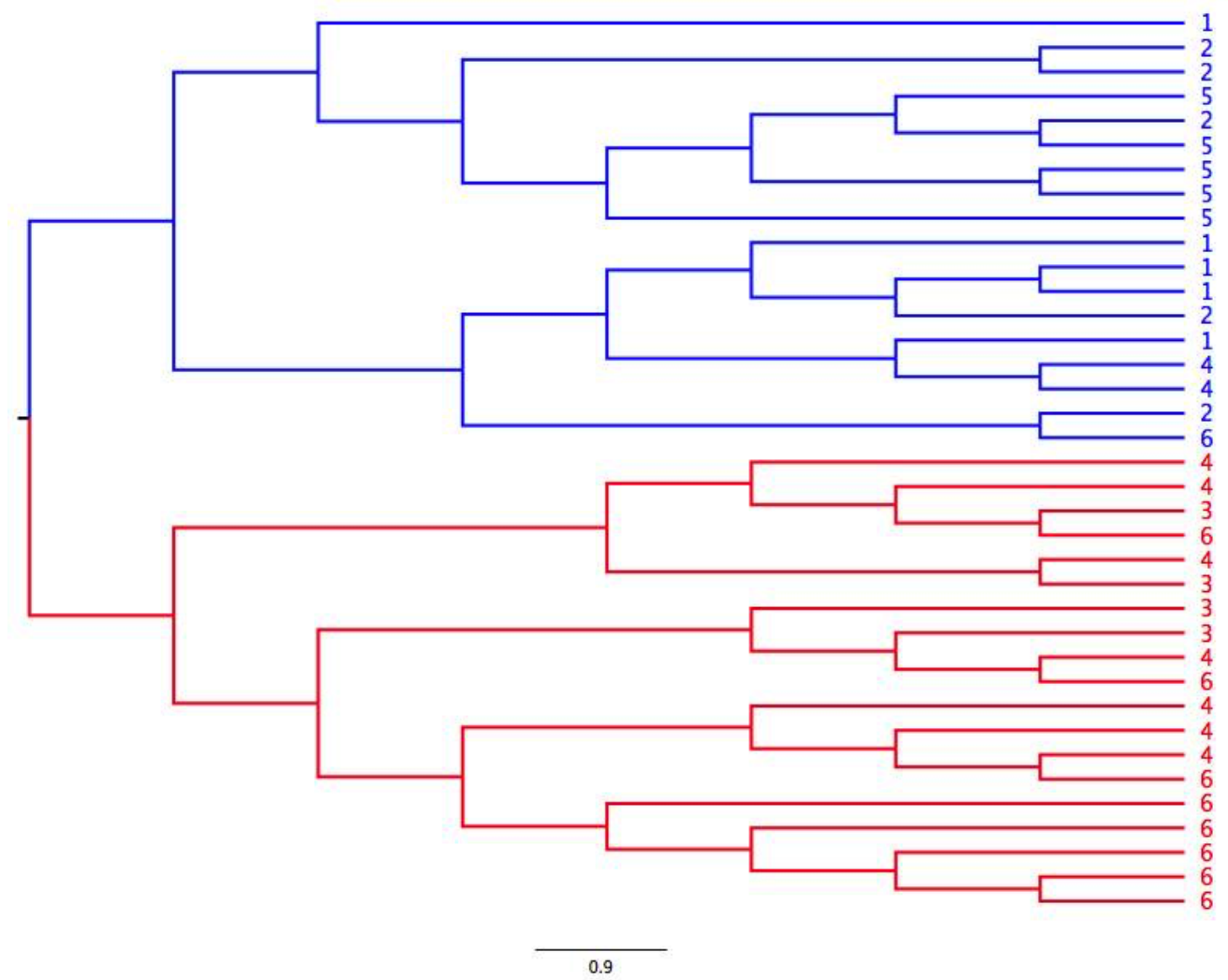

Fig. 2. UPGMA tree of the studied populations based on the morphological data (Populations 1-6 are according to Table 1). 


\section{Anatomy}

The stem in cross-section was quadrangular. A one - layered epidermis was seen, which had elongated cell. The length of epidermal cell varied between the studied populations. Collenchyma cells were observed as a large area in all corners. The size of collenchyma cell and its layer number differed among the populations. The stem cortex was composed of polygonal parenchyma cell that was found between collenchyma tissue and stele. The parenchyma cell layer no. and also size of parenchyma cell varied among the populations. The vascular bundle was collateral. In all of studied populations, the vascular bundles were bigger on the corner than other parts of stem. Beneath the phloem tissue, we have a 1 to 2 - layered cambium. The xylem tissue existing beneath the cambium was composed of regular trachea and tracheid cells. The pith consists of polygonal cells with intercellular spaces (Table 3).

Table3. Details of anatomical features in L. peltata populations studied (all values are in $\mu \mathrm{m}$ ).

$\begin{array}{lllll}\text { Population } & \text { Saqqez } & \text { Asera } & \text { Shahrestanak } & \text { Fasham Gachsar Gajereh }\end{array}$

\section{Characters}

Length of epidermal cell

Collenchyma cell length

Length of parenchyma cell

Sclerenchyma cell length

Length of upper phloem

Length of xylem

Length of lower phloem

Pith cell length

Stem diameter

Width of transects

Length of simple hair

Length of glandular hair

Parenchyma cell layer No

Collenchyma cell layer No

Xylem cell layer No

$\begin{array}{lll}1.2 & 1.4 & 2.0 \\ 7.1 & 8.9 & 16.9 \\ 4.9 & 4.6 & 9.0 \\ 2.8 & 2.1 & 2.7 \\ 5.0 & 3.1 & 6.5 \\ 8.1 & 3.3 & 8.8 \\ 2.3 & 2.9 & 3.9 \\ 58.2 & 42.7 & 75.6 \\ 87.6 & 84.2 & 129.9 \\ 65.2 & 74.1 & 105.0 \\ 3.7 & 6.7 & 9.7 \\ 2.5 & 2.7 & 4.2 \\ 6 & 6 & 9 \\ 3 & 2 & 4 \\ 5 & 4 & 5\end{array}$

2.0

9.0

2.7

6.5
8.8

3.9

75.6

129.9

105.0

9.7

4.2

9

5

$\begin{array}{lll}1.7 & 1.8 & 2.4 \\ 19.2 & 13.9 & 18.2 \\ 4.7 & 4.2 & 6.4 \\ 2.5 & 3.7 & 4.2 \\ 9.8 & 4.4 & 5.2 \\ 7.7 & 4.0 & 6.8 \\ 4.3 & 2.6 & 3.9 \\ 77.7 & 34.7 & 51.0 \\ 140.1 & 76.1 & 113.2 \\ 122.1 & 68.5 & 96.0 \\ 10.2 & 7.4 & 11.2 \\ 3.7 & 3.3 & 5.2 \\ 6 & 10 & 8 \\ 3 & 3 & 4 \\ 4 & 3 & 4\end{array}$

The PCoA plot (Fig. 4) of the studied populations based on the anatomical characters revealed closer affinity between populations Saqqez, Asera, and Gachsar. Similarly, Shahrestanak, Fasham, and Gajereh populations were placed close to each other. This is in agreement with our morphological result.

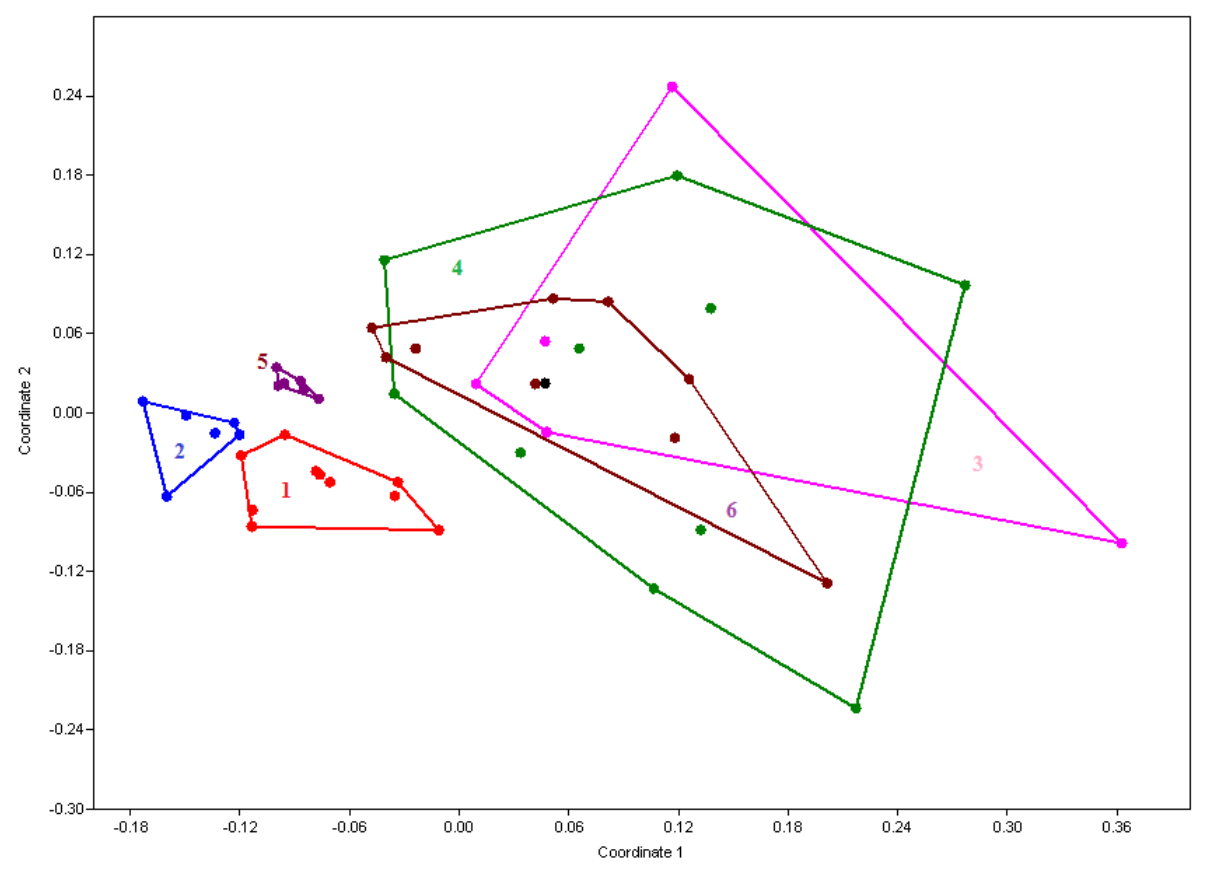

Fig. 3. PCoA plot of L. peltata populations studied based on morphological characters (Populations 1-6 are according to Table 1). 
PCA analysis revealed that the first three PCA components comprised about $60 \%$ of the total variations. PCA loading revealed that anatomical traits like length of epidermal cell, collenchyma and parenchyma cell layers number had the highest positive correlation (>0.7). These are the most variable anatomical characters among the studied populations, which mainly differentiate the populations Asera and Gachsar, from the others.

\section{ISSR analysis}

In total, 45 ISSR bands (Loci) were obtained. Some of the bands were private and occurred in Saqqez, Fasham, and Gajereh populations (Table 4). These bands can differentiate the studied populations.

Table 4. Details of ISSR bands obtained in L. peltata populations studied.

\begin{tabular}{lllllll}
\hline Population & Saqqez & Asera & Shahrestanak & Fasham & Gachsar & Gajereh \\
No. Bands & 31 & 23 & 14 & 35 & 21 & 20 \\
$=<$. No. Bands Freq 0.5\% & 31 & 23 & 14 & 35 & 21 & 20 \\
No. Private Bands & 4 & 0 & 0 & 4 & 0 & 1 \\
=> No. LComm Bands(50\%) & 10 & 6 & 3 & 12 & 5 & 8 \\
\hline
\end{tabular}

Genetic diversity parameters in L. peltata (Table 5) revealed that the highest degree of genetic polymorphism and gene diversity occurred in Fasham population ( $77 \%$ and 0.21 respectively), followed by Saqqez population (62\% and 0.16 respectively). In general moderate to high degree of genetic variability occurred in L. peltata populations. This is probably related to out-breed nature of this species.

Table 5. Genetic diversity parameters determined in the studied populations.

\begin{tabular}{llllllll}
\hline Population & $\mathrm{N}$ & $\mathrm{Na}$ & $\mathrm{Ne}$ & $\mathrm{I}$ & $\mathrm{He}$ & $\mathrm{uHe}$ & $\% \mathrm{P}$ \\
Saqqez & 10,000 & 1,311 & 1,249 & 0,255 & 0,160 & 0,168 & $62,220 \%$ \\
Asera & 6,000 & 0,889 & 1,274 & 0,225 & 0,154 & 0,168 & $37,780 \%$ \\
Shahrestanak & 5,000 & 0,622 & 1,126 & 0,140 & 0,087 & 0,097 & $31,110 \%$ \\
Fasham & 10,000 & 1,556 & 1,335 & 0,338 & 0,214 & 0,226 & $77,780 \%$ \\
Gachsar & 6,000 & 0,889 & 1,265 & 0,232 & 0,156 & 0,170 & $42,220 \%$ \\
Gajereh & 10,000 & 0,889 & 1,192 & 0,180 & 0,115 & 0,121 & $44,440 \%$ \\
\hline
\end{tabular}

AMOVA produce significant genetic difference among the studied populations (PhiPT $=0.34, P=0.01$ ). It also revealed that $35 \%$ of total genetic difference occurred among populations, while $65 \%$ was due to within population genetic variability. This indicates that the studied populations have a good level of within population genetic variability. Pair-wise AMOVA revealed significant genetic difference among all studied populations. This is further supported by MDS plot of the populations based on ISSR data (Fig. 5). The plants of the studied populations form a separate group in the MDS plot, which indicates genetic divergence of these populations. Saqqez, Asera, and Gachsar populations showed a close genetic affinity based on ISSR data, while Saqqez, Fasham, and Gajereh populations were placed close to each other. This is in agreement with morphological and anatomical results.

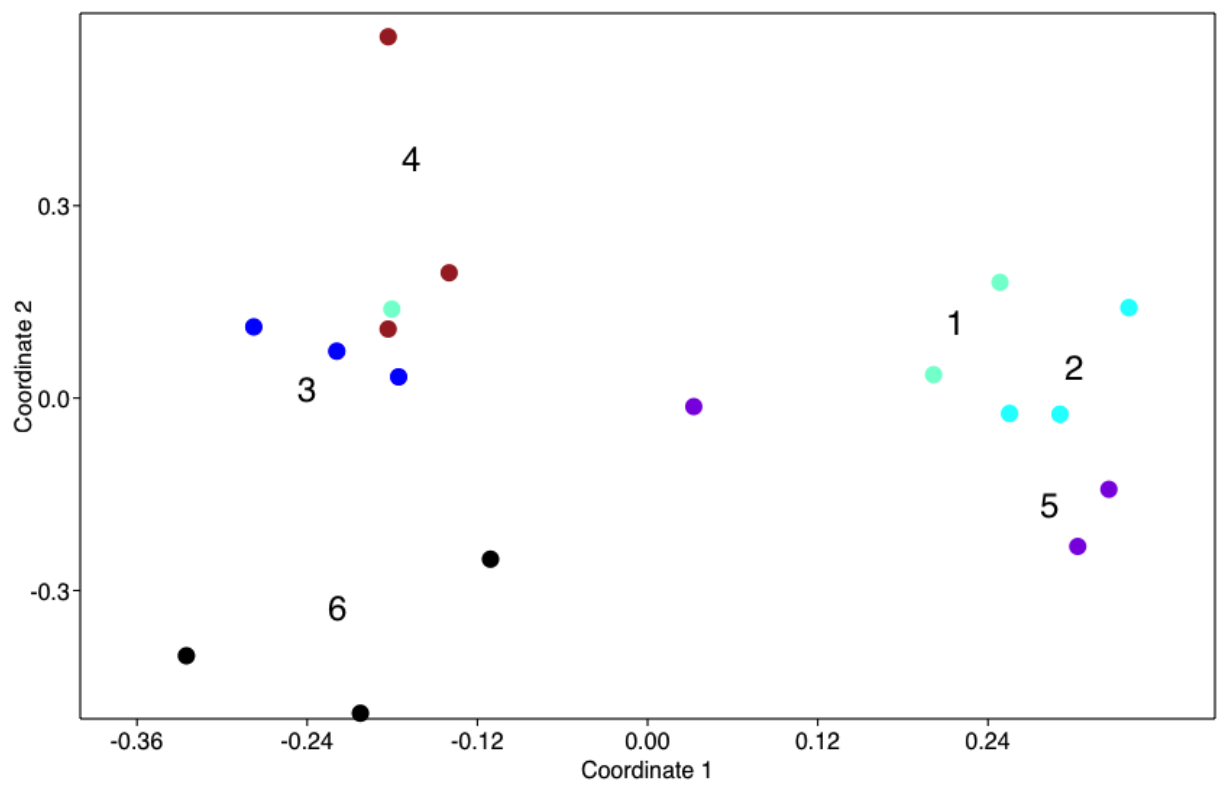
Table 1).

Fig. 4. PCoA plot of L. peltata populations studied based on anatomical features (Populations 1-6 are according to 
The Ivanno test performed on STRUCTURE analysis produced $\mathrm{k}=2$ as the optimal genetic group. The STRUCTURE plot based on k = 2 (Fig. 6) revealed close genetic affinity between Saqqez, Asera populations, followed by Gachsar population (they have similarly coloured segments, mostly green colour). Similarly, Shahrestanak and Gajereh populations showed close genetic similarity (mostly red coloured segments); while Fasham population showed the genetic content of both these groups (both green and red coloured).

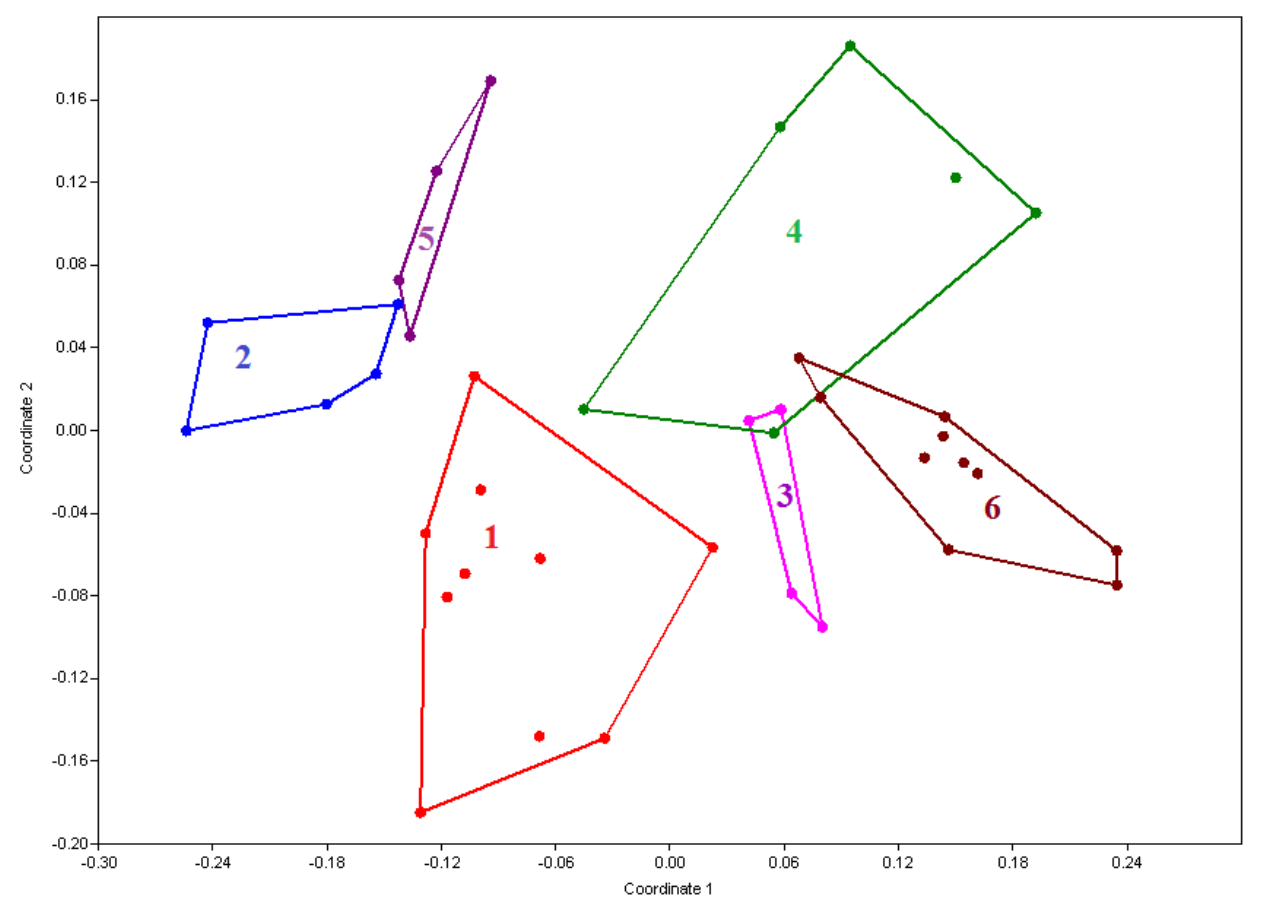

Fig. 5. MDS plot of L. peltata populations studied based on ISSR data (Populations 1-6 are according to Table 1).

\section{Discussion}

In the current study, we used morphological, anatomical and also ISSR molecular data for investigation of infraspecific variations among L. peltata populations in Iran. Classification and taxonomic consideration of within species diversity may be diverse by different authors, for example, Sheidai et al., (2013) studied 38 geographical populations in four Cirsium Mill. species and treated divergent geographical populations as different ecotypes.

This species has restricted distribution in the country and is only found in some mountain slopes occasionally with more than $900 \mathrm{~km}$ distance. Instances of infra-specific variation are known in different plant species with extensive geographical distribution (see for example, Sheidai et al., 2012, 2013).

Results of morphological data showed that high morphological divergence exists among the populations and they are divided into two groups.

Although several taxa of Lamiaceae family are studied anatomically (Özdemir, Altan, 2005; Aktaş et al., 2009), we have no anatomical study of $L$. peltata in literature. Therefore we used stem anatomical traits for investigations of infraspecific variations among the populations of this species. Various studies proved that stem anatomical characteristics are very important in plant taxonomy. Hagstroem (1916) mainly stressed the importance of stem anatomical characters for recognizing new taxa. He partly went too far in his appreciation of stem anatomy traits, particularly with respect to the recognition of hybrids. Symoens et al., (1979) used stem anatomy for the distinction between two very similar African taxa.

Our studied populations had quadrangle stem with a multi-layered collenchyma at corners. The vascular tissue is collateral, and the thickness of xylem is bigger than phloem. Metcalfe and Chalk (1972) have stated that the anatomical characteristic traits of Labiatae family are a quadrangular stem with a well-developed collenchyma, supporting tissue at the corners of stem. The mentioned traits are previously reported in some other investigated taxa of the family by different authors (e.g. Bosabalitis, Kokkini 1997; Gönüz, Özörgücü, 1999; Dinç et al., 2008).

PCA analyses showed that some anatomical features were more variable than others. In similar to morphological analyses, the studied populations were divided into two groups.

Inter simple sequence repeat (ISSR) is a PCR-based molecular marker technique, which has been proven to be highly useful for investigating genetic diversity and population genetic structure of different plant taxa (Zietkiewicz et al., 1994; Godwin et al., 1997; Archak et al., 2003). Hence, in the present investigation, we used this technique to reveal the genetic diversity and population genetic structure of L. peltata. 
ISSR data showed genetic variations among these populations and divided them into two different groups similar to morphological and anatomical data. The STRUCTURE analyses proved separation of populations.

These populations not only showed morphological divergence, but also differed in anatomical and genetic content. All these data support the idea that we have different subspecies or varieties in this plant species.

When morphological population divergence is accompanied with genetic divergence we may consider these populations as distinct infra-specific taxa. In the Alpine Alps (NW Tuscany), several plant species occur as populations that are morphologically, genetically and ecologically distinct. Such natural groups are treated as sub-specific rank. This type of taxonomic treatment has been reported for a number of taxa in the different genera like Buphthalmum L. (Compositae), Rhinanthus L. (Scrophulariaceae), Astrantia L. (Umbelliferae), and Asperula (Rubiaceae) (Bechi, Garbari, 1994).

\section{Conclusion}

In the current study, morphological, anatomical and also molecular ISSR technique was used for investigating infraspecific variations among $L$. peltata populations in Iran. This species has very restricted distribution in Iran, however against restricted distribution of $L$. peltata high infraspecific variations were recorded among its populations. The results of morphological, anatomical and molecular analyses were similar. In all studies, the studied populations divided into two similar groups. In one group Saqqez, Asera and Gachsar populations were clustered closely and other populations made another groups. This pattern of arrangement confirmed existence of possible infraspecific taxonomic ranks within this species.

\section{References}

Aktaş, K., Özdemir, C., Özkan M., Akyol, Y., Baran, P. (2009). Morphological and anatomical characteristics of Salvia tchihatcheffii endemic to Turkey. African Journal of Biotechnology, 8(18), 4519-4528.

Archak, S., Gaikwad, A. B., Gautam, D. et al. (2003.) Comparative assessment of DNA fingerprinting techniques (RAPD, ISSR and AFLP) for genetic analysis of cashew (Anacardium occidentale L.) accessions of India. Genome, 46, 362-369

Bechi, N., Garbari, F. (1994). Intraspecific variation and taxonomic aspects of some plants from the Apuan Alps (Tuscany, Italy). Flora Mediterranea, 4, 213-225.

Bosabalitis, A.M., Kokkini, S. (1997). Infraspecific variation of leaf anatomy in Origanum vulgare grown wild in Greece. Botanical Journal of the Linnean Society, 123, 353-362.

Caliński, R.B., Harabasz, J. (1974). A dendrite method for cluster analysis. Communications in statistics, 3, 1-27.

Dinç, M., Duran, A., Pinar, M., Öztürk, M. (2008) Anatomy, palynology and nutlet micromorphology of Turkish endemic Teucrium sandrasicum (Lamiaceae). Biologia, 63(5), 637-641.

Evanno, G., Regnaut, S., Goudet, J. (2005). Detecting the number of clusters of individuals using the software STRUCTURE: a simulation study. Molecular Ecology, 14, 2611-2620.

Falush, D., Stephens, M., Pritchard, J.K. (2007). Inference of population structure using multilocus genotype data: dominant markers and null alleles. Molecular Ecology Resources, 7, 574-578.

Freeland, J.R., Kirk, H., Petersen, S. (2011). Molecular Genetics in Ecology. Molecular Ecology, Second Edition.

Godwin, I. D., Aitken, E. A. B., Smith, L. W. (1997). Application of inter simple sequence repeat (ISSR) markers to plant genetics. Electrophoresis, 18, 1524-1528.

Gönüz, A., Özörgücü, B. (1999). An investigation on the morphology, anatomy and ecology of Origanum onites L. Turkish Journal of Botany, 23, 19-32.

Hagstroem, J. O. (1916). Critical researches on the PotanIOgetons. Kung!. Svenska Vetenskapsakad. Handlingar 55(5), $1-281$.

Hammer, $\varnothing .$, Harper, D.A.T., Ryan, P. D. (2012). PAST: Paleontological Statistics software package for education and data analysis. Palaeontologia Electronica, 4, 9-11.

Hedrick, P. W. (2005). A standardized genetic differentiation measure. Evolution, 59, 1633-1638.

Jamzad, Z. (2012). Flora of Iran no. 76: Lamiaceae. Research Institute of Forests and Rangelands, Tehran.

Koohdar, F., Sheidai, M., Talebi, S.M., Noormohammadi Z. (2015). Population genetic structure in medicinal plant Lallemantia iberica (Lamiaceae). Biodiversitas, 16, 139-144.

Mahmood, S., Hayat, M.Q., Sadiq, A., Ishtiaq, S.H., Malik, S., Ashra, M. (2013). Antibacterial activity of Lallemantia royleana Benth. indigenous to Pakistan. African journal of microbiology research, 7, 4006-4009.

Maxted, N., Hunter, V. (2011). Crop Wild Relatives: A Manual of in situ Conservation. Experimental Agriculture, 47, 735.

Meirmans, P.G. (2012). AMOVA-based clustering of population genetic data. The Journal of Heredity, 103, 744-750.

Meirmans, P.G., Van, Tienderen, P.H. (2004). GENOTYPE and GENODIVE: two programs for the analysis of genetic diversity of asexual organisms. Molecular Ecology Notes, 4, 792-794.

Metcalfe, C.R. \& Chalk, L. (1972). Anatomy of the Dicotyledons. Leaves, Stem, and Wood in Relation to Taxonomy. With Notes on Economic Uses, Oxford University Press, Oxford.

Özdemir, C., Altan, Y. (2005). Morphological and anatomical investigations on endemic Scutellaria orientalis L. subsp. bicolor (Hochst) Edmund and subsp. santolinoides (Hausskn ex Bornm). Pakistan Journal of Botany, 37(2), 213-226. 
Peakall, R., Smouse, P.E. (2006). GENALEX 6: genetic analysis in Excel. Population genetic software for teaching and research. Molecular Ecology Resources, 6, 288-295.

Podani, J. (2000). Introduction to the Exploration of Multivariate Data. Backhuyes.

Pritchard, J.K., Stephens, M., Donnelly, P. (2000). Inference of population structure using multilocus genotype data. Genetics, 155, 945-959.

Rechinger, K.H. (1982). Lallemantia. In: Rechinger K.H. (Ed.). Flora Iranica, vol. 150. Akademische Druck-U: Verlagsanstalt, Graz, Austria.

Rivera, D., Obón, C. (1992). The ethnobotany of old world Labiatae. Advances in Labiatae Science, 437-454.

Sefidkon, F., Sonboli, A., Kalvandi, R. (2006). Analysis of the essential oil of Lallemantia peltata from Iran. Journal of Essential Oil Bearing Plants, 9, 42-46.

Sheidai, M., Seif, E., Nouroozi, M., Noormohammadi, Z. (2012). Cytogenetic and molecular diversity of Cirsium arvense (Asteraceae) populations in Iran. Japanese Journal of Botany, 87, 193-205.

Sheidai, M., Zanganeh, S., Haji-Ramezanali, R., Nouroozi, M., Noormohammadi, Z., Ghsemzadeh-Baraki, S. (2013). Genetic diversity and population structure in four Cirsium (Asteraceae) species. Biologia, 68, 384-397.

Sheidai, M., Ziaee, S., Farahani, F., Talebi, S.M., Noormohammadi, Z., Hasheminejad Ahangarani Farahani, Y. (2014). Infra-specific genetic and morphological diversity in Linum album (Linaceae). Biologia, 69, 32e39

Symoens, J. J., Velden, J. Van De Bueschner, P. (1979). Contribution a l'etude de la taxonomie et de la distribution de Potamogeton nodosus POIRET et Potamogeton thunbergii Cham. Et Schlechtend. en Afrique. Bulletin of the Société royale de botanique de Belgique, 112, 79-95.

Weising, K., Nybom, H., Pfenninger, M., Wolff, K., Kahl, G. (2005). DNA fingerprinting in plants: principles, methods, and applications: CRC press.

Zietkiewicz, E., Rafalski, A., Labuda, D. (1994). Genome fingerprinting by simple sequence repeat (SSR)-anchored polymerase chain reaction amplification. Genomics, 20, 176-183

\section{Citation:}

Sheidai, M., Poode, Z.M., Koohdar, F., Se Talebi, S.M. (2018). Infra-specific morphological, anatomical and genetic variations in Lallemantia peltata (L.) Fisch. \& C. A. Mey. (Lamiaceae). Acta Biologica Sibirica, 4 (3), 85-93.

Submitted: 21.06.2018. Accepted: 13.08.2018

cross ref http://dx.doi.org/10.14258/abs.v4i3.4412

(C) 2018 by the authors. Submitted for possible open access publication under the terms and conditions of the Creative Commons Attribution (CC BY) license (http://creativecommons.org/licenses/by/4.0/). 